\title{
METIPRANOLOL-INDUCED ADVERSE REACTIONS: I. THE RECHALLENGE STUDY
}

\author{
TAYO AKINGBEHIN*, JOSE R. VILLADA*, TOM WALLEY† \\ Southport and Liverpool
}

\begin{abstract}
SUMMARY
Previously unreported adverse drug reactions can be difficult to detect and it may be even more difficult to establish a cause and effect relationship, particularly if the adverse reacions mimic naturally occurring disease. In a previous paper we reported 29 patients with granulomatous anterior uveitis, blepharoconjunctivitis, periorbital dermatitis, marginal keratitis and elevation in intraocular pressure (IOP), suspected to be caused by metipranolol (Glauline). With the approval of the District Ethics Committee 7 of those patients were rechallenged with metipranolol $0.3 \%$ compared to timolol maleate $0.5 \%$ in a double blind trial. The 7 metipranolol treated eyes developed an adverse reaction within 14 days. Metipranolol (Glauline) has been conclusively proven to cause granulomatous anterior uveitis, blepharoconjunctivitis and elevation in IOP, adverse effects never previously reported with any of the ophthalmic topical beta-blockers. The multidose preparations of metipranolol (Glauline) in all three strengths $0.1 \%, 0.3 \%$ and $0.6 \%$ and the single dose minim preparation of metipranolol $0.6 \%$ have now been withdrawn from clinical use in the United Kingdom.
\end{abstract}

Topical beta-blockers have become very popular in the treatment of glaucoma since the first, timolol, was introduced in 1978. All topical beta-blockers were thought to have a similar side effect profile, with rare serious systemic effects such as bronchospasm, and few ocular adverse effects. These ocular effects could be divided into the subjective (burning and stinging on instillation, eye pain, foreign body sensation) and the objective (external eye inflammation, punctate keratopathy, dry eye syndrome and corneal anaesthesia). ${ }^{1}$ Intraocular inflammation had not previously been described as an adverse effect of these drugs.

Metipranolol (Glauline, Smith and Nephew) is a topical

From: *The Department of Ophthalmology, Southport and Formby District General Hospital; †The Department of Pharmacology, University of Liverpool.

Correspondence to: Mr Tayo Akingbehin MD, FRCS, FCOphth, Department of Ophthalmology, Southport and Formby District General Hospital, Southport. beta-blocker licensed in the United Kingdom for the treatment of glaucoma in 1986, although it was in widespread use in Europe for many years before that and was recently marketed in the United States (1991). Some authors suggested that metipranolol was less well tolerated than other beta-blockers with a high incidence of subjective but not objective side effects. ${ }^{2,3}$ In February 1990, we saw 5 cases of either granulomatous anterior uveitis or blepharoconjunctivitis or both in patients using metipranolol. These associations were reported by "yellow card" to the Committee on Safety of Medicines (CSM) who had one previous report of iritis with this drug and to the Pharmaceutical Company who had no previous reports either from Germany or the United Kingdom where more than 700,000 prescriptions had been issued up to 1990 (Smith \& Nephew, personal communication).

We suspected that metipranolol was responsible for these inflammatory reactions and undertook a review of all of our patients on this drug. The details have been published elsewhere. ${ }^{4}$ Since this association has not been previously described, we felt that it was important to establish a cause and effect relationship. We therefore identified further patients who had developed ocular inflammation whilst receiving metipranolol and with their consent rechallenged with this drug.

\section{RECHALLENGE STUDY}

The protocol for this study was submitted to the District Ethics Committee and approval obtained.

After full explanation patients gave written consent for the following study: double blind comparison between metipranolol $0.3 \%$ and timolol $0.5 \%$. It was felt to be unethical to use placebo in glaucoma patients and therefore timolol was used as the comparable drug. All patients had pre-trial IOPs controlled by other ophthalmic topical beta-blockers.

Patients were given two identical bottles, labelled right eye and left eye, one containing metipranolol $0.3 \%$ and the other timolol maleate $0.5 \%$ eye drops in a randomised fashion. Patients were told to apply two drops from the appropriate bottle twice a day. Patients were given enough 
Table I. Reasons for failure to complete the study

\begin{tabular}{lc}
\hline Reason & No of patients \\
\hline Unexplained non-attendance & 3 \\
Illness & 2 \\
Holiday & 1 \\
\hline
\end{tabular}

drug for two weeks, at which time they returned to the clinic for review.

Patients were to be reviewed every two weeks but had access to the investigators at all times. The study was intended to last a maximum of six months but was to be terminated at any time if the patient wished or if signs of ocular inflammation or elevation in IOP developed.

Before entering the study all the patients underwent: (1) full medical history and ocular examination including the measurement of visual acuity, IOP and grading of the following parameters (using scores from 0-3), watering, blurring, photophobia, conjunctival injection, corneal oedema, keratic precipitates (KPs), aqueous flare, aqueous cells, anterior vitreous cells, hypopion and posterior synechia.

(2) chest X-ray.

(3) full blood count, erythrocyte sedimentation rate, urea and electrolytes, VDRL, toxoplasma and toxocara serology, serum angiotensin converting enzyme and fasting blood sugar.

\section{RESULTS}

Thirteen patients agreed to participate in the rechallenge but only 7 ( 2 males, 5 females, mean age 71.5 years) completed the study. The reasons for the withdrawal of 6 patients are given in Table I.

The previous adverse effects suffered by the 7 patients were bilateral granulomatous anterior uveitis in 4 patients; unilateral granulomatous anterior uveitis in 2 patients and periorbital dermatitis in 1 patient. Of the 2 patients with unilateral granulomatous anterior uveitis, 1 was receiving metipranolol in both eyes and the other in the affected eye only.

Screening of these patients showed that 1 had positive toxoplasma serology, and another had non-insulin dependent diabetes mellitus. In neither case was it thought that these contributed to the inflammation or the elevation in IOP.

All of the patients developed an objective documented adverse reaction in the eye which was treated with metipranolol $0.3 \%$ within 2-14 days and the trial was terminated in each case. Three eyes of 3 patients had granulomatous anterior uveitis, 2 eyes of 2 patients had blepharoconjunctivitis, 1 eye of 1 patient had periorbital dermatitis, and 1 eye of the seventh patient which was white and quiet on examination had a rise in IOP from 25 $\mathrm{mmHg}$ pre-trial to $42 \mathrm{mmHg}$ (Table II). One of the patients (No 3) who developed metipranolol-induced granulomatous anterior uveitis had co-existing blepharoconjunctivitis with secondary ectropion due to the skin changes and loss of IOP control ( $\triangle \mathrm{IOP} 22 \mathrm{mmHg}$ ). None of the eyes which received timolol showed any adverse reactions during the period of the study, 5 of these eyes had pre-trial metipranolol-induced adverse events.

The 2 eyes with blepharoconjunctivitis and 2 of the 3 eyes with granulomatous anterior uveitis were treated immediately with topical steroids and they all showed complete resolution of symptoms and signs within two weeks. The third eye with granulomatous anterior uveitis, 1 eye with periorbital dermatitis and 1 eye with loss of intraocular pressure control did not receive any active treatment following the termination of the trial drug. These 3 eyes also showed complete resolution of symptoms and signs within two weeks. All the 7 eyes with metipranolol associated adverse reactions were later treated with another anti-glaucoma medication (timolol in 6 eyes and levobunolol in 1 eye) and have shown no adverse reaction to the alternative topical beta-blocker to date.

\section{DISCUSSION}

Definitive proof of cause and effect relationship in adverse drug reactions can be difficult to obtain. Naranjo et al. ${ }^{5}$ laid down certain criteria which ideally should be fulfilled to prove causality, although this is not always possible.

These criteria are-

(1) The event should be described frequently and hence be well documented.

(2) The event should improve on withdrawal of the drug.

(3) Other possible causes for the adverse event should be excluded.

(4) The event should be more severe with increased dose of the drug.

(5) There should be objective evidence of the adverse event.

(6) The patients should suffer a similar effect with similar drugs.

(7) The event should recur on challenge with the suspected drug.

The most powerful of these criteria is whether the adverse effect recurs on challenge with the suspected drug. The results of this rechallenge study provides unequivocal evidence that metipranolol causes periorbital dermatitis, blepharoconjunctivitis, granulomatous anterior

Table II. Distribution of ADRs in patients pre and post rechallenge. Time of patients withdrawal

\begin{tabular}{lccccc}
\hline & \multicolumn{2}{c}{ pre-trial ADRs } & \multicolumn{2}{c}{ rechallenge ADRs } & Time \\
Patient & Reaction & Eyes involved & Metipranolol & Timolol & (days) \\
\hline 1 & GAU & LE & GAU (LE) & N.A. & 5 \\
2 & GAU & RE + LE & BC (LE) & nil (RE) & 2 \\
3 & GAU & RE + LE & GAU + BC + & nil (RE) & 14 \\
& & & ectropion + & & \\
4 & GAU & RE & IOP (LE) & & \\
5 & GAU & RE + LE & GAU (RE) & nil (LE) & 14 \\
6 & POD & RE + LE & POD (LE) & nil (LE) & 7 \\
7 & GAU & RE + LE & BC (LE) & nil (RE) & 14 \\
\hline
\end{tabular}

GAU granulomatous anterior uveitis

BC blepharoconjunctivitis

POD periorbital dermatitis

IOP intraocular pressure

N.A. not applicable 
uveitis and elevation in IOP. What is not immediately apparent in this study is whether all these adverse reactions are various stages of a specific metipranolol-induced syndrome. Unfortunately the study was unable to address this question because the investigators were bound by the ethics of the trial to terminate the rechallenge once there was an objective evidence of adverse reaction. However, from previous review of all patients receiving metipranolol by the authors, there is evidence to suggest that the various types of reaction can occur in isolation for months without progression. These reactions have also been found in combination. This lack of specificity in the type of response to metipranolol is pathologically quite interesting.

It has been suggested that a possible explanation for these adverse reactions, which appear to have been reported mainly in the United Kingdom, is the sterilisation of the multidose metipranolol bottles by gamma radiation from January 1989 . There is no scientific evidence to support this view and we have identified patients in the United Kingdom with metipranolol associated adverse reactions who received multidose metipranolol bottles sterilised by ethylene oxide pre-1989. Also in Europe, where the bottles of metipranolol are not sterilised by radiation, there were at least 9 spontaneous adverse reaction reports of anterior uveitis (Germany 5, France, Holland and Switzerland 4) by early 1991 before the publication of our report, ${ }^{4}$ (Smith and Nephew - personal communication).

One of the main privileges which the law bestows on registered medical practitioners is the right to prescribe and we owe it to our patients to remain vigilant with regard to adverse drug reactions and communicate all unwanted and unexpected events to the CSM using the "yellow card" scheme. It is only by reporting all suspected events to a central agency that evidence can be gathered quickly and effective action taken to alert clinicians of post-marketing adverse reactions. "Vigilance is important but so is serendipity" (Prescriber's Journal 1991, vol 31, no 1 Editorial).

Our thanks to Sister Anne E Lewis, the Committee on Safety of Medicines, Celia Lloyd-Jones and the Pharmacy Department in Southport and Formby District General Hospital for help in carrying out this study.

Key words: Anterior Uveitis, Beta-blockers, Blepharocon-junctivitis, Metipranolol, Timolol.

\section{REFERENCES}

1. Akingbehin $\mathrm{T}$ and Sunder Raj P: Ophthalmic topical betablockers: Review of ocular and systemic side effects. $J$ Toxicol-Cut \& Ocular Toxicol 1990, 9:(2) 131-47.

2. Krieglstein GK, Novack GD, Voepel E et al: Levobunolol and metipranolol: comparative ocular hypotensive efficacy, safety and comfort. Br J Ophthalmol 1987, 71: 250-3.

3. Kruse W: Metipranolol - ein neuer beta rezeptoren blocker. Klin Montabl Augenheilkd 1983, 182: 582-4.

4. Akingbehin $\mathrm{T}$ and Villada JR: Metipranolol-associated granulomatous anterior uveitis. Br J Ophthalmol 1991, 75: 519-23.

5. Naranjo CA, Busto U, Sellers EM, et al: A method for estimating the probability of adverse drug reactions. Clin Pharmacol Therap 1981, 30: 239-45. 